\title{
ARTÍCULOS
}

\section{Companion crops upon Eucalyptus urograndis initial development}

\author{
Efecto de cultivos asociados sobre el desarrollo inicial de Eucalyptus urograndis
}

\author{
Délio Braga Marques a , Pedro de Figueiredo Rocha Barbosa Martins a*,

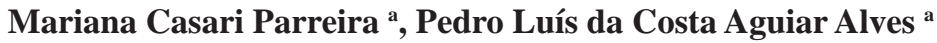

\author{
*Corresponding author: ${ }^{\text {a }}$ Universidade Estadual Paulista Júlio de Mesquita Filho, FCAV/UNESP, \\ Departamento de Biologia Aplicada à Agropecuária, Laboratório de Plantas Daninhas, \\ Via de Acesso Prof. Paulo Donato Castellane s/n, CEP:14884-900, Jaboticaba, Brasil, martins.pfrb@gmail.com
}

\begin{abstract}
SUMMARY
The present work aims at evaluating the initial development of two Eucalyptus urograndis (eucalypt) clones (H017 and H1069) consorted with maize in six plants per meter; soy in eighteen plants per meter; beans in ten plants per meter; and signal-grass, with 0.5 $\mathrm{kg} \mathrm{m}^{-2}$ of seeds. The eucalypt planting was upheld in cement vases $-70 \mathrm{~L}$ of capacity, filled with red oxisol- in the center of the vase. The crops were sown equidistant from the border, in one or two sowing lines. A randomized block design was used, in a 5x2 factorial scheme, using five crops (maize, bean, soy, signal grass and control treatment) in two densities (one and two sowing lines), all with three repetitions. Ninety days after planting, eucalypt height, diameter, foliar area, dry matter of leaves and stem and crops aerial parts dry matter were evaluated. Consort crops negatively affected the initial development of both clones, especially in the density of two sowing lines. Bean and soy were the least harmful crops and maize and signal-grass were the most harmful crops.
\end{abstract}

Key words: eucalypt, agroforestal systems, polyculture.

\section{RESUMEN}

El presente trabajo tuvo como objetivo evaluar el desarrollo inicial de dos clones de Eucalyptus urograndis (H017 y H1069) intercalados con maíz, soya, frijol y Brachiaria decumbens. La parcela experimental consistió en una planta de eucalipto con una fila o dos de un cultivo. Se utilizó un diseño de bloques al azar, en esquema factorial 5x2, siendo cinco cultivos (maíz, frijol, soya, Brachiaria decumbens y un tratamiento testigo) en dos poblaciones (una y dos líneas de siembra), todos con tres repeticiones. A los 90 días después de plantados, se evaluó la altura, el diámetro, el área foliar y peso seco de hojas y tallos de E. urograndis, y la masa seca de la parte aérea de los cultivos. Los cultivos intercalados afectaron negativamente el desarrollo inicial de los dos clones, especialmente cuando la convivencia de E. urograndis era con dos líneas de siembra. Frijol y soja fueron los cultivos que ofrecieron menor interferencia y maíz y Brachiaria decumbens fueron los de mayor interferencia a las plantas de E. urograndis.

Palabras clave: eucalipto, plantas acompañantes, sistemas agroforestales.

\section{INTRODUCTION}

In order to unite forestry to crop systems, agroforestry systems appear as relatively interesting, especially due to high costs when implanting and maintaining forests and the necessity of conducting crop systems in a more naturefriendly way. In agroforestry systems, tree species are used associated with crops simultaneously or sequentially, with the purpose of optimizing economic rent of such enterprises (Macedo et al. 2001).

Agroforestry systems may be defined as a combination of simultaneous or sequential cropping of native or exotic tree species with agricultural crops. This management is part of a bigger productive system: grains, fibers, meat, milk, wool, bio-energy, among others, that are all harvested in the same area; thus, reducing the biological cycles of each species and diminishing residues from any species, aiming at a sustainable system (Macedo 2009).

These systems may be used in areas in which long monocultures or inadequate cropping practices were or are still being conducted, which bring degradation of natural resources and productivity losses (Kichel et al. 1999). In this case, livestock-crops-forestry integration becomes a viable alternative to revert damage, improving the area productivity and making it capable of recovering soil conditions.

According to Peron and Evangelista (2004), the Cerrado in Brazil has $80 \%$ of its pastures are degraded or in 
some level of degradation. For these, the agroforestry system is more beneficial, as it does improve soil conditions, such as fertility and physical structure; allows the farmer to have higher incomes through different periods, as it diversifies production, and makes the area less susceptible to market variance (Kluthcouski and Yokoyama 2003).

Tree species to be used in those systems must have low fertility soil adaptation, high productivity and resistance to cutting, pasturing and diseases (Huxley 1983). In this context, Eucalyptus species have a high potential to be used in these systems.

In order to successfully establish agroforestry, the species to be consorted must be accounted. The ecological relation between these species must be harmonious, as one must bring benefits to the other (Braz et al. 2010). Therefore, many essays have been made to evaluate the best consorting and management techniques.

This essay aims at evaluating the initial growth of two eucalypt (Eucalyptus urograndis, hybrid of E. grandis Hill ex Maid. and E. urophylla S.T. Blake) clones (H017 and H1069) co-existing with Brachiaria brizantha (Hochst. ex A. Rich.) Stapf. (signal-grass), Glycine max (L.) Merr. (soybean), Zea mays L. (maize) and Phaseolus vulgaris L. (bean) crops.

\section{METHODS}

The essay was conducted from January $18^{\text {th }}$ to April 21 ${ }^{\text {st }}$, 2011, at the Weeds Studies Laboratory (Laboratório de Plantas Daninhas - LAPDA), Universidade Estadual Paulista Júlio de Mesquita Filho - UNESP, Jaboticabal Campus, Brazil.

The experimental parcels were cement vases, $70 \mathrm{~L}$ capacity, filled with arable soil from an Oxisol plot. The chemical analysis was conducted, as shown in table 1. Fertilizers were applied in order to enable the crops to develop normally as stated in Cantarella et al. (1996).

Eucalyptus urograndis clones H017 (higher plants, less diameter) and H0169 (lower plants, fast diameter gain) at 90 days were transplanted.

Seven days after planting (DAP), the following crops were sown: Urochloa decumbens Stapf. (signal grass), at $0.5 \mathrm{~kg}$ seeds per meter; maize (DKB390YG hybrid), at six plants per meter; soybean (RR7908 MONSOY cultivar), at 18 seeds per meter; and bean (Carioca group, 'Rubi' cultivar), at ten seeds per meter. The amount of seeds used for this essay was chosen in accordance with the amounts used in cultivating conditions.

Densities used were of one and two plants beside the eucalypt plant (at vase center), at $25 \mathrm{~cm}$ from the vase border and all lines equidistant from $E$. urograndis.

The experiment was conducted at a $5 \times 2$ factorial scheme for each clone as of five crops (signal grass, soybean, bean, maize and a control plot, with only one E. urograndis plant per vase); two densities were used, all with three replications.
Through the essay period, two nitrogen fertilizations took place, using urea as fertilizer: first at 30 DAP and the second one at 45 DAP, applying a $300 \mathrm{~kg} \mathrm{ha}^{-1}$ dose. Irrigation and hand weeding were performed whenever necessary.

Ninety DAP, the eucalypt stem diameter, eucalypt height, foliar area, and leaves and stem dry matter, and dry matter of consort crops were evaluated. Diameter was attained with a digital caliper next to the base; height was measured through the stem height with a one-meter-long ruler.

Foliar area was determined in a Li-Cor Instruments LI3000A measurer, through scanning each leaf, and dry matter through convection oven drying at $70{ }^{\circ} \mathrm{C}$ until constant mass, being weighted in a 0.01 precision scale.

Results were submitted to variance analysis (F test) and means compared through Tukey test at $5 \%$ probability, using SISVAR software (Ferreira 2000).

\section{RESULTS}

There were interaction effects between densities and crops upon height, diameter, foliar area and stem dry matter of eucalypt clone H017 (table 2).

Regarding height, when analyzing crop effects upon each density, eucalypt specimens that coexisted with signal grass in a single line density differed from the control plot. When in two lines, bean and soybean coexisting specimens were bigger than maize and control ones.

As for diameter, analyzing crop effects upon each density, the control plot showed better development compared to every other treatment, independently of sown density. In one line density, bean was the crop that more diminished eucalypt diameter. When in two lines, almost every treatment caused reduction when compared to the control plot, except for bean.

As for foliar area, analyzing crop effect upon each density, the control plot had bigger area in both densities. In one line density, maize and soybean were the most detrimental crops to eucalypt, reducing an average of $37 \%$. As for signal grass and bean, they diminished 23 and $13 \%$. The same pattern was attained in two sown lines, being soybean the most detrimental crop, reducing $69 \%$.

Analyzing leaves dry matter content, there was significant reduction from every crop studied, being two lines sowing results even lower. As for stem dry matter content, analyzing crop effect upon each density, signal grass and the control plot presented the highest values. The other crops showed lower, not different, results when sown in one line. As for two lines density, the control plot had the highest matter content, differing from the other crops studied.

When analyzing density effect upon each crop (table 3), no difference was attained for soybean or bean to the eucalypt specimens in any density. As for maize and signal grass, there were reductions of dry matter content when sown in two lines. 
Table 1. Physical and chemical analyses of soil used on the experiment.

Análisis físico y químico del suelo del área experimental.

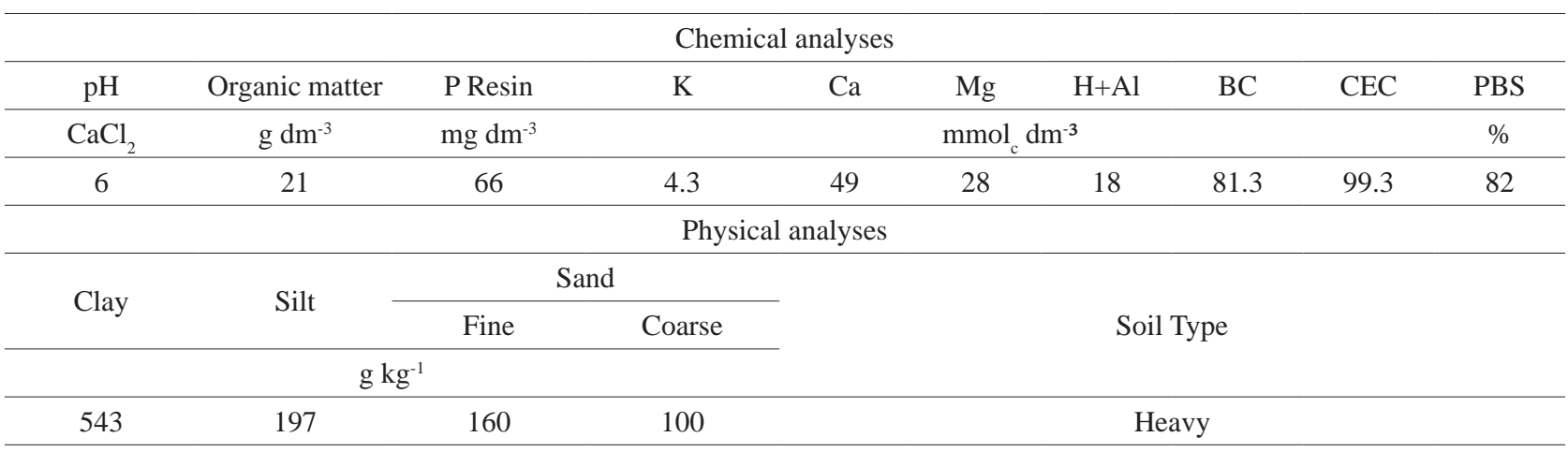

BC: base cations (sum of K, Ca and Mg); CEC: cation exchange capacity (sum of BC and H+Al); PBS: percentage base saturation (100*BC/CEC, indicator of liming necessity if low values) (Sonon et al. 2014).

Table 2. Effect of density and crops upon height (H), stem diameter (D), foliar area (FA) and dry matter of leaves (DML) and stem (DMS) of H017 clone at 90 DAP.

Efecto de la densidad de plantas y de los cultivos en la altura (H), diámetro del tallo (D), área foliar (FA) y materia seca de las hojas (DML) y del tallo (DMS) de H017 clon a los 90 DAP.

\begin{tabular}{|c|c|c|c|c|c|}
\hline Factor & $\mathrm{H}(\mathrm{cm})$ & $\mathrm{D}(\mathrm{mm})$ & $\mathrm{FA}\left(\mathrm{cm}^{2}\right)$ & DML (g) & DMS (g) \\
\hline \multicolumn{6}{|l|}{ Density } \\
\hline One & $64.2 \mathrm{~B}$ & $8.8 \mathrm{~A}$ & $661 \mathrm{~A}$ & $38.8 \mathrm{~A}$ & $39.4 \mathrm{~A}$ \\
\hline Two & $68.8 \mathrm{~A}$ & $7.6 \mathrm{~B}$ & 494.13 B & $27.1 \mathrm{~B}$ & 29.9 B \\
\hline \multicolumn{6}{|l|}{ Crop } \\
\hline Maize & $61.5 \mathrm{C}$ & 7.6 B C & $468 \mathrm{E}$ & $18.0 \mathrm{C}$ & $26.9 \mathrm{C}$ \\
\hline Soybean & $73.3 \mathrm{~A}$ & $7.0 \mathrm{C}$ & 398 D & $22.4 \mathrm{C}$ & $27.8 \mathrm{C}$ \\
\hline Bean & $65.3 \mathrm{BC}$ & 7.3 B C & 643 B & $21.6 \mathrm{C}$ & $29.4 \mathrm{C}$ \\
\hline Signal & $72.0 \mathrm{AB}$ & $8.1 \mathrm{~B}$ & $534 \mathrm{C}$ & $35.4 \mathrm{~B}$ & $40.9 \mathrm{~B}$ \\
\hline Control & $60.3 \mathrm{C}$ & $11.0 \mathrm{~A}$ & 844 A & $67.5 \mathrm{~A}$ & $48.2 \mathrm{~A}$ \\
\hline $\mathrm{Fc}$ & $11.02 *$ & $41.83^{*}$ & $847.45^{*}$ & $259.42 *$ & $39.08 *$ \\
\hline Fd & $8.25^{* *}$ & $28.15^{*}$ & $964.01 *$ & $106.77 *$ & $49.11 *$ \\
\hline $\mathrm{Fc} * \mathrm{Fd}$ & $6.97 * *$ & $14.78^{*}$ & $83.35 *$ & $15.39 *$ & $16.03 *$ \\
\hline VC (\%) & 6.59 & 7.52 & 2.54 & 9.41 & 10.69 \\
\hline
\end{tabular}

Means followed by different letters on the column differ statistically through Tukey test at $5 \%$.

*,** - Significant at $5 \%$ and $1 \%$, respectively, through $\mathrm{F}$ test.

$\mathrm{Fc}=$ Variable factor crop; $\mathrm{Fd}=$ Variable factor density; $\mathrm{Fc} * \mathrm{Fd}=$ Interaction of factors crop*density .

Statistical analyses show density interaction between density and crops upon height, stem diameter, foliar area and stem dry matter of $\mathrm{H} 0169$ clone at 90 DAP (table 4). Height, when analyzing crop effect upon each density, in one line density, only signal grass caused significant reduction from the control plot mean. As for two lines, maize reduced eucalypt height. As for density effect upon crops, maize was the only crop in which rising from one- to twoline sowing diminished height. For diameter, analyzing effects of crop upon each density, it was verified eucalypt plants coexisting with signal grass, one line, were bigger than the control plot, and the other crops reduced this parameter. As for two sown lines, the control plot had higher diameter values. No matter which crop, two lines sowing damaged eucalypt when compared to one-line sowing.

Regarding foliar area, when analyzing crop effect upon each density, every treatment caused a reduction of mean values when compared to the control plot. Analyzing density effect upon each crop, there was no difference between sown densities among soybean treatments. As for the other crops, they reduced foliar area when sown in two lines instead of one. For stem dry matter, analyzing crop 
Table 3. Effect of density and crop interaction upon H017 clone plants height (H), diameter (D), foliar area (FA), dry matter of leaves (DML) and dry matter of stem (DMS) at 90 DAS.

Efecto de la interacción cultivo y densidad de plantas sobre la altura (H), el diámetro (D), el área foliar (FA) y el contenido de materia seca de hojas (DML) y tallos (DMS) del clon H017 a los 90 DAP.

\begin{tabular}{|c|c|c|c|c|c|c|c|c|c|c|}
\hline \multirow{3}{*}{ Crop } & \multicolumn{10}{|c|}{ Density } \\
\hline & One & Two & One & Two & One & Two & One & Two & One & Two \\
\hline & \multicolumn{2}{|c|}{$\mathrm{H}(\mathrm{cm})$} & \multicolumn{2}{|c|}{$\mathrm{D}(\mathrm{mm})$} & \multicolumn{2}{|c|}{$\mathrm{FA}\left(\mathrm{cm}^{2}\right)$} & \multicolumn{2}{|c|}{ DML (g) } & \multicolumn{2}{|c|}{ DMS (g) } \\
\hline Maize & $60.0 \mathrm{BCa}$ & $63.0 \mathrm{Ba}$ & 8.7 BCa & $6.4 \mathrm{Cb}$ & $532 \mathrm{Da}$ & $405 \mathrm{Cb}$ & $27.2 \mathrm{Ca}$ & $8.8 \mathrm{Cb}$ & $32.6 \mathrm{Ba}$ & 21.2 Bb \\
\hline Soybean & $70.0 \mathrm{ABa}$ & 76.7 Аа & 7.8 CDa & $6.2 \mathrm{Cb}$ & $538 \mathrm{Da}$ & $257 \mathrm{Db}$ & $24.8 \mathrm{Ca}$ & $20.1 \mathrm{Ba}$ & $28.4 \mathrm{Ba}$ & 27.2 Ba \\
\hline Bean & $55.7 \mathrm{Cb}$ & $75.0 \mathrm{Aa}$ & $6.5 \mathrm{Db}$ & 8.0 Ba & $736 \mathrm{Ba}$ & $549 \mathrm{Bb}$ & $27.1 \mathrm{Ca}$ & 16.1 BCb & $32.0 \mathrm{Ba}$ & $26.8 \mathrm{Ba}$ \\
\hline Signal & 75.0 Аа & 69.0 Aba & $9.8 \mathrm{ABa}$ & $6.4 \mathrm{Cb}$ & $652 \mathrm{Ca}$ & $415 \mathrm{Cb}$ & $47.6 \mathrm{Ba}$ & $23.1 \mathrm{Bb}$ & 55.7 Аа & $26.0 \mathrm{Bb}$ \\
\hline Control & $60.3 \mathrm{BCa}$ & $60.3 \mathrm{Ba}$ & 11.0 Аа & 11.0 Аа & 845 Аа & 845 Аа & 67.5 Аа & $67.5 \mathrm{Aa}$ & 48.2 Аа & 48.2 Аа \\
\hline MSDd & \multicolumn{2}{|c|}{3.34} & \multicolumn{2}{|c|}{0.47} & \multicolumn{2}{|c|}{11.18} & \multicolumn{2}{|c|}{2.36} & \multicolumn{2}{|c|}{2.82} \\
\hline MSDc & \multicolumn{2}{|c|}{7.58} & \multicolumn{2}{|c|}{1.05} & \multicolumn{2}{|c|}{25.36} & \multicolumn{2}{|c|}{5.36} & \multicolumn{2}{|c|}{6.4} \\
\hline
\end{tabular}

Means followed by different letters on the column (upper-case) or line (lower-case) differ statistically through Tukey test at $5 \%$, in each parameter. MSD: Minimum significant difference for density (d) and crops (c).

Table 4. Effect of density and crops upon height (H), stem diameter (D), foliar area (FA) and dry matter of leaves (DML) and stem (DMS) of H1069 clone at 90 DAP.

Efecto de la densidad de plantas y de los cultivos en la altura (H), diámetro del tallo (D), área foliar (FA) y materia seca de las hojas (DML) y del tallo (DMS) de clon H1069 a los 90 DAP.

\begin{tabular}{lccccc}
\hline \multicolumn{1}{c}{ Factor } & $\mathrm{FA}\left(\mathrm{cm}^{2}\right)$ & $\mathrm{D}(\mathrm{mm})$ & $\mathrm{H}(\mathrm{cm})$ & DMS $(\mathrm{g})$ & $\mathrm{DML}(\mathrm{g})$ \\
\hline Density & & & & \\
\hline \multicolumn{1}{c}{ One } & $606 \mathrm{~A}$ & $8.8 \mathrm{~A}$ & $62.3 \mathrm{~A}$ & $44.5 \mathrm{~A}$ & $35.0 \mathrm{~A}$ \\
\multicolumn{1}{c}{ Two } & $526 \mathrm{~B}$ & $7.3 \mathrm{~B}$ & $58.8 \mathrm{~B}$ & $36.1 \mathrm{~B}$ & $30.2 \mathrm{~B}$ \\
\hline Crop & & & & \\
\hline \multicolumn{1}{c}{ Maize } & $442 \mathrm{D}$ & $6.8 \mathrm{D}$ & $53.5 \mathrm{C}$ & $25.9 \mathrm{D}$ & $20.6 \mathrm{C}$ \\
$\quad$ Soybean & $351 \mathrm{E}$ & $7.9 \mathrm{C}$ & $63.0 \mathrm{AB}$ & $30.2 \mathrm{D}$ & $17.3 \mathrm{C}$ \\
Bean & $660 \mathrm{~B}$ & $6.5 \mathrm{D}$ & $62.2 \mathrm{AB}$ & $37.8 \mathrm{C}$ & $32.5 \mathrm{~B}$ \\
Signal & $567 \mathrm{C}$ & $9.2 \mathrm{~B}$ & $59.0 \mathrm{~B}$ & $43.4 \mathrm{~B}$ & $29.2 \mathrm{~B}$ \\
$\quad$ Control & $811 \mathrm{~A}$ & $9.8 \mathrm{~A}$ & $65.0 \mathrm{~A}$ & $64.1 \mathrm{~A}$ & $63.5 \mathrm{~A}$ \\
\hline Fc & $423.86^{*}$ & $121.93^{*}$ & $16.58^{*}$ & $153.15^{*}$ & $154.16^{*}$ \\
Fd & $101.86^{*}$ & $158.33^{*}$ & $12.86^{* *}$ & $61.14^{*}$ & $12.85^{* *}$ \\
FC*Fd & $36.07^{*}$ & $19.79^{*}$ & $10.35^{*}$ & $6.26^{* *}$ & $2.54^{\text {ns }}$ \\
VC (\%) & 3.79 & 4.05 & 4.46 & 7.33 & 11.09 \\
\hline
\end{tabular}

Means followed by different letters differ statistically through Tukey test at $5 \%$.

effect upon each density, the control plot presented higher dry matter allocation. Maize and soybean treatments affected the most the dry matter allocation (table 4).

When two lines were sown, crops led to reduction of stem dry matter content, especially maize. Every crop in this study, when sown in two lines, promoted lower dry matter allocation when compared to those sown in one line (table 5).
Dry matter of crops for 'H017' clone (table 6) showed statistical differences between sown densities. Significant differences were also verified between crops and density factors.

As for 'H0169' clone coexisting consort crops dry matter (table 6), it is noticed that densities had interaction effects and the crop and density factors had significant interactions in between. 
Table 5. Effect of density and crop interaction upon H1069 clone plants height (H), diameter (D), foliar area (FA) and dry matter of stem (DMS) at 90 DAS.

Efecto de la interacción cultivo y densidad de plantas sobre la altura (H), el diámetro (D), el área foliar (FA), y el contenido de materia seca de tallos (DMS) del clon H1069 a los 90 DAP.

\begin{tabular}{|c|c|c|c|c|c|c|c|c|}
\hline \multirow{3}{*}{ Crop } & \multicolumn{8}{|c|}{ Density } \\
\hline & One & Two & One & Two & One & Two & One & Two \\
\hline & \multicolumn{2}{|c|}{$\mathrm{H}(\mathrm{cm})$} & \multicolumn{2}{|c|}{$\mathrm{D}(\mathrm{mm})$} & \multicolumn{2}{|c|}{$\mathrm{FA}\left(\mathrm{cm}^{2}\right)$} & \multicolumn{2}{|c|}{ DMS (g) } \\
\hline Maize & $61.0 \mathrm{ABa}$ & $46.0 \mathrm{Bb}$ & 7.5 Da & $6.0 \mathrm{Cb}$ & $565 \mathrm{Ca}$ & $319 \mathrm{Cb}$ & $33.6 \mathrm{Ca}$ & $18.2 \mathrm{Db}$ \\
\hline Soybean & $64.5 \mathrm{Aa}$ & $61.5 \mathrm{Aa}$ & $8.4 \mathrm{Ca}$ & $7.3 \mathrm{Bb}$ & $349 \mathrm{Da}$ & $354 \mathrm{Ca}$ & $33.2 \mathrm{Ca}$ & $27.2 \mathrm{Cb}$ \\
\hline Bean & $64.0 \mathrm{Aa}$ & $60.3 \mathrm{Aa}$ & $7.2 \mathrm{Da}$ & $5.7 \mathrm{Cb}$ & $715 \mathrm{Ba}$ & $599 \mathrm{Bb}$ & $44.2 \mathrm{Ba}$ & $31.3 \mathrm{Cb}$ \\
\hline Signal & $57.0 \mathrm{Ba}$ & 61.0 Аa & $10.8 \mathrm{Aa}$ & $7.5 \mathrm{Bb}$ & $586 \mathrm{Ca}$ & $548 \mathrm{Bb}$ & 47.4 Ba & $39.5 \mathrm{Bb}$ \\
\hline Control & $65.0 \mathrm{Aa}$ & $65.0 \mathrm{Aa}$ & $9.8 \mathrm{Ba}$ & 9.8 Аа & 811 Аа & 811 Аа & $64.1 \mathrm{Aa}$ & $64.1 \mathrm{Aa}$ \\
\hline MSDd & \multicolumn{2}{|c|}{2.06} & \multicolumn{2}{|c|}{0.25} & \multicolumn{2}{|c|}{16.32} & \multicolumn{2}{|c|}{2.25} \\
\hline MSDc & \multicolumn{2}{|c|}{4.66} & \multicolumn{2}{|c|}{0.56} & \multicolumn{2}{|c|}{3704} & \multicolumn{2}{|c|}{5.1} \\
\hline
\end{tabular}

Means followed by different letters on the column (upper-case) or line (lower-case) differ statistically through Tukey test at $5 \%$, in each parameter. MSD - Minimum significant difference for density (d) and crops (c).

Table 6. Interaction effect of density and crop upon crops dry matter (g) at 90DAP for clones H017 and H1069.

Efecto de la interacción de densidad de plantas y tipo de cultivo sobre el contenido de materia seca (g) de los mismos asociados a los 90 DAP para los clones H017 y H1069.

\begin{tabular}{lcc}
\hline Factor & Clone H017 & Clone H1069 \\
\hline Density & & \\
\hline \multicolumn{1}{c}{ One } & $108.4 \mathrm{~B}$ & $114.2 \mathrm{~B}$ \\
\multicolumn{1}{c}{ Two } & $159.3 \mathrm{~A}$ & $144.1 \mathrm{~A}$ \\
\hline Crop & & \\
$\quad$ Maize & $347.8 \mathrm{~A}$ & $290.3 \mathrm{~A}$ \\
\multicolumn{1}{c}{ Soybean } & $30.1 \mathrm{C}$ & $27.6 \mathrm{C}$ \\
\multicolumn{1}{c}{ Bean } & $30.8 \mathrm{C}$ & $37.8 \mathrm{C}$ \\
$\quad$ Signal & $126.6 \mathrm{~B}$ & $161.1 \mathrm{~B}$ \\
\hline FC & $816.38^{*}$ & $710.58^{*}$ \\
Fd & $94.38^{*}$ & $41.75^{*}$ \\
FC*Fd & $29.85^{*}$ & $27.44^{*}$ \\
VC (\%) & 9.59 & 8.77 \\
NMS & 0.05 & 0.05 \\
\hline
\end{tabular}

Means followed by different letters differ statistically, amongst the same clone, through Tukey test at $5 \%$.

*, **: Significant at $5 \%$ and $1 \%$, respectively, through $\mathrm{F}$ test. ns: Non significant through $\mathrm{F}$ test.

Concerning dry matter of consort crops coexisting with 'H017' clone (table 7), when analyzing crop effect upon density, it showed maize had higher dry matter allocation whereas soybean and bean had the least matter, when sown in one line. The same pattern is followed by two-line sowing. As for the density effect upon each crop, maize and signal grass had higher allocation and bean and soybean showed no difference.

For 'H1069' clone's dry matter of consort crops (table 7), analyzing crop effect upon each density, higher dry matter values were attained by maize and lower values by the legumes, for one- as well as for two-line sowing.

Again, maize and signal grass had higher dry matter allocation when sown in two lines. Legumes had no difference between densities.

Table 7. Interaction effect of density and crop upon crops dry matter (DMC, g) consorted to H017 and H1069 clones at 90 DAP.

Efecto de la densidad de plantas por tipo de cultivo sobre el contenido de materia seca (DMC, g) de los mismos asociados a los clones H1069 y H1069 a los 90 DAP.

\begin{tabular}{lcrcc}
\hline \multirow{2}{*}{ Crop } & \multicolumn{2}{c}{ Clone H017 } & \multicolumn{2}{c}{ Clone H1069 } \\
\cline { 2 - 5 } & \multicolumn{1}{c}{ One } & \multicolumn{1}{c}{ Two } & One & Two \\
\hline Maize & $283.2 \mathrm{Ab}$ & $412.5 \mathrm{Aa}$ & $240.8 \mathrm{Ab}$ & $339.8 \mathrm{Aa}$ \\
Soybean & $24.8 \mathrm{Ca}$ & $35.5 \mathrm{Ca}$ & $22.7 \mathrm{Ca}$ & $32.5 \mathrm{Ca}$ \\
Bean & $27.8 \mathrm{Ca}$ & $33.7 \mathrm{Ca}$ & $44.2 \mathrm{Ca}$ & $31.4 \mathrm{Ca}$ \\
Signal & $97.8 \mathrm{Bb}$ & $155.5 \mathrm{Ba}$ & $149.3 \mathrm{Bb}$ & $173.0 \mathrm{Ba}$ \\
\hline MSDd & \multicolumn{2}{c}{11.11} & \multicolumn{2}{c}{9.81} \\
MSDc & \multicolumn{2}{c}{21.2} & \multicolumn{2}{c}{18.73} \\
\hline
\end{tabular}

Means followed by different letters on the column (upper-case) or line (lower-case), amongst the same clone, differ statistically through Tukey test at $5 \%$. 


\section{DISCUSSION}

After 90 DAP, almost every characteristic evaluated in eucalypt plants were negatively influenced by crop consorting maize, soybean, bean and signal grass. As this result is common to both clones, it may be related to the proximity of sowing and the eucalypt in the vases, which may lead to competition for natural resources.

Most of the bean-eucalypt consorting brought better results, despite this system having some negative effects upon the eucalypt. Couto et al. (1990), in the Rio Doce Valley - Minas Gerais, relate that the initial growth of $E$. grandis in a $3 \times 2 \mathrm{~m}$ spacing consorted to bean is not negatively affected, and even favors the diameter increase, as well as the bean productivity. It was also verified by Schreiner and Balloni (1986) that bean-eucalypt consorting favors the forest species nitrogen harnessing due to the N-fixing capacity of the legume species and due to the favorable environmental conditions for the initial growth, as the bean covered the soil.

In this essay, the fact may have not been too clear as the lines may have been too close to the clones. There is also the possibility that this proximity may have prevented the normal development of the clones, as the type III bean growth tends to occupy empty lateral spaces; eventually reaching the eucalypt plant, shadowing it, reducing its photosynthetic rate. During the experiment, the bean stalks tangled into the eucalypt trunk, reducing the foliar exposure to the sun. As it can be seen in Table 4, the second sowing density proportioned higher values of height than those shown in the first density. Because of the increase of plants per vase, the bean had to grow upwardly, rather than laterally, generating a competition for light resources with the eucalypt, causing it to etiolate.

It is also observed that results attained with soybean were different from those with bean, which was not the expected income, as bean and soybean are from the same botanical family and should share similar behavior, thus similarly affecting the eucalypt. Couto et al. (1982) in Bom Despacho - MG, experimenting similarly to Schreiner and Baloni (1986), stated the eucalypt growth was not affected by soybean cropping and the weeding operation necessity was lower, yielding the same as a single cropping in that region and reducing the reforestation costs. These authors also cite three facts for which soybean was favorable to the eucalypt: the fertilizers used in the soybean were also harnessed by the eucalypt, the $\mathrm{N}$-fixing capacity of soybean decreases the fertilizer uptake from the soil and the favorable environmental conditions developed by the soil covering attribute of soybean plants.

However, is it necessary to observe the spacing used, avoiding the interference of crop over tree, as in the same essay, Couto et al. (1982) attained overly distinct wood yields with relatively near spacing and population densities (five lines spaced of 50 and $40 \mathrm{~cm}$ ), though the fact was not specified.
Results achieved by consorting signal grass were not expected either, since its aggressiveness to eucalypt is well related and its interference was lower than other species used in this essay. This income may be linked to the fact that signal grass was not at its full growth and potential at the end of the experimental period. According to Dinardo et al. (2003) and Toledo et al. (2001), eucalyptuses, during their initial growth, are highly affected by panic grass and signal grass from a low population density (4 plants $\left.\mathrm{m}^{-2}\right)$. Even more, as in the experiment made by Cruz et al. (2010), the eucalypt characteristics more sensitive to panic grass are foliar area, leaves and stem dry matter, similar to the results achieved by signal grass coexistence. In the present essay, signal grass showed superior or similar results to those shown by control plot specimens and other crops studied.

Results achieved by Silva et al. (1997) show that Eucalyptus citriodora Hook. plants are more sensitive to signal-grass coexistence than is E. grandis. These results display the effects of interference, since severity is different through the species, as affirmed by Bleasdale (1960), Blanco (1972) and Pitelli (1985).

It was stated that results obtained for maize are related to its height and sowing distance to eucalypt. Such facts made the values attained in the essay be lower than expected, as it inflicted damage to photosynthetic rates and generated a competition for water and nutrients. This may be certified by Macedo et al. (2000), as they relate fast growth species establishing potential capacity is commonly observed on field, during the first post-planting stages, through percentage of survival, certifying the maize consorted to eucalypt does not affect the crop, as long as spacing is right. According to Daniel (1996), the first maize line, when sown at $0.45 \mathrm{~m}$ from the Eucalyptus sp., simultaneously to the trees planting, caused great reduction to the tree initial development. In an essay cited by Taiz and Zeiger (2004), it was shown what plants submitted to shadowing tend to etiolate in order to reach sunlight, justifying this way the results achieved by the evaluated parameters when maize is sown at $12.5 \mathrm{~cm}$ from Eucalyptus sp.

The difference between clones height evidences that these show different genetic exploration capacities, of habitat productive potential, being attributed to the phenotypical plasticity, in where 'H017' tends to grow more in height, whereas 'H1069' tends to grow in diameter.

Golfari (1975) states the growth in height is one of the main parameters to determine the establishment of trees in competition situation, being one of the most secure parameters to prove if the species is or is not planted in an adequate place.

In the present essay, many significant differences are noticed related to tree diameter; being this related to the diminishing of foliar area, causing the lesser nutrient allocation to E. urograndis and, thus, reducing diameter and stem and leaves dry matter.

Many researches show diameter is very afflicted by different spacing (Bernardo 1995, Oliveira Neto et al. 2003, Nascimento et al. 2012). 
Bernardo (1995) studied the behavior of three eucalypt species at Minas Gerais Cerrado area, regarding growth and nutritional efficiency. The author also observed that lower spacing showed negative effects upon height and diameter for the three studied species. And at $3 \times 1.5 \mathrm{~m}$ spacing, the highest intraspecific interference was attained. This fact allows saying that, besides the competition between the Eucalyptus sp. and the consort crops, lower spacing results in a competition among the crops themselves.

Oliveira Neto et al. (2010), evaluating Eucalyptus camaldulensis Dehn. in different spacing and crescent fertilization rates, at the Cerrado region of Minas Gerais, attested the diameter growth had positive influence from spacing and fertilizing rates, being the highest value attained at $15 \mathrm{~m}^{2}$ and 2.8 times fertilizing.

Results attained by authors such as Patiño-Valera (1986), Gomes (1994) and Bernardo (1995) show that most forest species with fast growth habits, when diameter growth is studied, are usually related to bigger planting spacing, which enables to say the clones used in this essay were affected by the proximity of crop sowing to the eucalypt saplings.

The analyzed treatments, independent of consorted crops, interfered negatively in the initial growth of both clones, due mainly to the proximity of the crops sown in the vase.

Bean and soybean are good alternatives to eucalypt consorting, considering the benefits those crops bring; nevertheless, the management practices that must occur must be well planned and the right spacing must be well studied.

Maize and signal grass must be better studied, owing to their effects on competition for nutrients, water and light resources.

Attending also to the fact that the crops were placed next to saplings, as it is verified through attained data that maize and signal grass dry matter content were higher than those of bean and soybean, it is evident that those are more dependent on higher fertilizing and irrigation, higher spacing and other managements when consorted to Eucalyptus sp.

\section{REFERENCES}

Bernardo AL. 1995. Crescimento e eficiência nutricional de Eucalyptus spp. sob diferentes espaçamentos na região de cerrado Minas Gerais. Dissertation in Forestal Sciences. Viçosa, Brazil. Universidade Federal de Viçosa. 102 p.

Blanco HG. 1972. A importância dos estudos ecológicos nos programas de controle de plantas daninhas. Biológico 38 (10): 343-350.

Bleasdale JKA. 1960. Studies on plant competition. In Harper JL ed. The biology of weeds. Oxford, United Kingdom. Blackweel Scientific Publications. p. 133-142.

Braz AJBP, HJ Kliemann, PM Silveira. 2010. Produtividade de palhada de plantas de cobertura. In Silveira PM, LF Stone eds. Plantas de cobertura dos solos do cerrado. Santo Antônio de Goiás, Brazil. Embrapa Arroz e Feijão. 218 p.

Cantarella H, JA Quaggio, AMC Furlani. 1996. Recomendações de adubação e calagem para o estado de São Paulo. Campinas, Brazil, Instituto Agronômico de Campinas. 285p.

Couto L, CAM Passos, LR Capitani. 1990. Consorciação de Eucalyptus grandis W. Hill ex Maiden com cultura agrícola anual no Vale do Rio Doce, Minas Gerais. In Congresso Florestal Brasileiro, 6, Campos do Jordão. São Paulo, Brazil. SBS. p. 256-259.

Couto L, NF Barros, GC Rezende. 1982. Interplanting soybean with eucalypt as a 2-tier agroforestry venture in southeastern Brazil. Austalian Forest Resarch 12 (1): 329-32.

Cruz MB, PLCA Alves, DKaram, AS Ferraudo.2010. Capimcolonião e seus efeitos sobre o crescimento inicial de clones de Eucalyptus $\times$ urograndis. Ciência Florestal 20(3): 391-401.

Daniel O. 1996. Teste de espécies/procedências de Eucalyptus spp. em Dourados (MS). I- resultados aos 42 meses de idade. Revista Cientifica - UFMS 3(1): 24-28.

Dinardo W, REB Toledo, PLCA Alves, RA Pitelli. 2003.Efeito da densidade de plantas de Panicum maximum Jacq. Sobre o crescimento inicial de Eucalyptus grandis W. Hill ex Maiden. Scientia Forestalis 64 (1): 59-68.

Ferreira DF. 2000. Análises estatísticas por meio do Sisvar para Windows versão 4.0. In 45a Reunião Anual da Região Brasileira da Sociedade internacional de Biometria. São Carlos, SP, Brazil. Universidade Federal de São Carlos. p. 255-258.

Golfari L. 1975. Zoneamento ecológico do Estado de Minas Gerais para reflorestamento. Belo Horizonte, Brazil. PND/ FAO/IBDF-BRA/71/545. 65 p.

Gomes RT. 1994. Efeito do espaçamento no crescimento e nas relações hídricas de Eucalyptus spp. na região de cerrado de Minas Gerais. Dissertation Forestal Sciences. Viçosa, Brazil. Universidade Federal de Viçosa. 85 p.

Huxley PA. 1983. Plant research and agroforestry. Nairobi, Kenya. ICRAF. 618 p.

Kichel AN, CHB Miranda, AH Zimmer. 1999. Degradação de pastagens e produção de bovinos de corte com a integração agricultura x pecuária. In I Simpósio de Produção de Gado de Corte. November 12th to 15th, 1999. Viçosa, Brazil. p. 201-234.

Kluthcouski J, LP Yokoyama. 2003. Opções de Integração Lavoura-Pecuária. In Kluthcouski J, H Aidar, LF Stone. Integração lavoura-pecuária. Santo Antônio de Goiás, Brazil. Embrapa Arroz e Feijão. p. 129-142.

Macedo MCM. 2009. Integração lavoura pecuária: o estado da arte e inovação tecnológicas. Revista Brasileira de Zootecnia 38 (1): 133-146.

Macedo RLG, N Venturim, JE Gomes, EMG Lima, FWF Dantas. 2000. Potencial de estabelecimento de clones de $\mathrm{He}$ vea brasiliensis Muell Arg. (seringueira) introduzidos em sistemas agroflorestais com castanha-do-brasil (Bertholletia excelsa Humb et Bompl), em Lavras-MG. In Simpósio Internacional Sobre Ecossistemas Florestais. Porto Seguro. Rio De Janeiro, Brazil. Biosfera. p. 159-161.

Macedo RIG, N Venturim, JE Gomes, EMG Lima. 2001. Princípios de agrossilvicultura como subsídios do manejo sustentável. Informe Agropecuário 29(1): 15-26.

Nascimento DF, PSS Leles, SN Oliveira Neto, RTS Moreira, JM Alonso. 2012. Crescimento Inicial de Seis Espécies Florestais em Diferentes Espaçamentos. Revista Cerne 18 (1): 159-265. 
Oliveira Neto SN, GG Reis, MGF Reis, JCL Neves. 2003. Produção e distribuição de biomassa em Eucalyptus camaldulensis Dehn. em resposta à adubação e ao espaçamento. Revista Árvore 27(1): 15-23.

Oliveira Neto SN, GG Reis, MGF Reis, HG Leite, JCL Neves. 2010. Crescimento e Distribuição de Eucalyptus camaldulensis em Diferentes Espaçamentos e Níveis de Adubação na Região de Cerrado de Minas Gerais. Revista Floresta 40(4): 755-762.

Patiño-Valera F. 1986. Variação genética em progênies de Eucalyptus saligna Smith e sua interação com espaçamentos. Dissertation in Forestal Sciences. Piracicaba, Brazil. Escola Superior de Agricultura Luiz de Queiroz. 192 p.

Peron AJ, AR Evangelista. 2004. Degradação de pastagens em regiões de cerrado. Ciência e Agrotecnologia 28(3): 655-661.

Pitelli RA. 1985. Interferência das plantas daninhas nas culturas agrícolas. Informe agropecuário 11(29): 16-27.

Schreiner HG, E Balloni. 1986. O Consórcio das culturas de Fei- jão (Phaseolus vulgaris L.) e eucalipto (Eucalyptus grandis W. Hill ex Maiden) no Sudeste do Brasil. Boletim de Pesquisa Florestal 12 (1): 83-104.

Silva W, AA Silva, T Sediyama, LHL Freitas. 1997. Altura e diâmetro de Eucalyptus citriodora e E. grandis, submetidos a diferentes teores de água em convivência com Brachiaria brizantha. Revista Floresta 27(1): 3-16.

Sonon, LS, DE Kissel, U Saha. 2014. Cation Exchange Capacity and Base Saturation. UGA Extension Circular 1040. Consulted 04 Apr. 2015. Available in http://extension.uga.edu/ publications/files/pdf/C\%201040_1.PDF

Taiz L, E Zeiger. 2004. Fisiologia vegetal. Porto Alegre, Brazil. Artmed. 623 p.

Toledo REB, W Dinardo, AJ Bezutte, PLCA Alves, RA Pitelli. 2001. Efeito da densidade de plantas de Brachiaria decumbens Stapf. sobre o crescimento inicial de mudas de $E u$ calyptus grandis W. Hill ex Maiden. Scientia Forestalis 60 (1): 109-117.

Recibido: 24.01 .14

Aceptado: 30.09.14 